\title{
THE RELATIONSHIPS BETWEEN FOOD ATTITUDES AND SOCIODEMOGRAPHIC DETERMINANTS AMONG STUDENTS OF THE THIRD AGE UNIVERSITY IN NORTHERN POLAND
}

\author{
Magdalena Tańska ${ }^{1}$ Ewa Babicz-Zielińska
}

${ }^{1}$ Pomeranian University in Slupsk, Institute of Health Science, Słupsk, Poland

${ }^{2}$ Gdańsk College of Health, Gdańsk, Poland

\begin{abstract}
Background. A thorough understanding of nutritional needs, food attitudes, and preferences are necessary for aging societies. So far the detailed studies on food attitudes and their determinants among elderly people were relatively scarce. Objective. This research was aimed at the determination of relationships between food attitudes and some sociodemographic features among elderly people, students of the Third Age University in Poland.

Material and methods. The study was conducted among 607 students of the Third Age University based on the authors' questionnaire. The survey was anonymous. The attitudes towards health benefits of foods, novel foods, light and organic foods, food as a reward and pleasure, restriction of food intake, and the packaging and composition of food were investigated.

Results. The relationships between attitudes and gender, age, education level, professional activity, BMI index, and economic status were differentiated. The positive attitudes over $50 \%$ were noticed only for the health benefits of foods and the packaging and composition of the food. For the other attitudes, the neutral attitudes were dominant. The three significant relations between attitudes and sociodemographic determinants were notices only for gender, two such relations were found for professional activity, the economic status and BMI index, and relations between age or education level - only for a single attitude.

Conclusions. The obtained results may be explained as a complex effect of specifics of this group and the overall tendency for conservative attitudes observed among elderly people. The food attitudes are significantly related to gender and other determinants become much less important for the surveyed group of the participants of the Third Age University.
\end{abstract}

Key words: food attitudes, elderly people, determinants of food choice

\section{STRESZCZENIE}

Wprowadzenie. Dokładne zrozumienie potrzeb żywieniowych, percepcji i preferencji żywieniowych najstarszego pokolenia jest niezbędne dla starzejących się społeczeństw. Dotychczas nieliczne są szczegółowe badania dotyczące postaw żywieniowych i ich uwarunkowań wśród ludzi starszych.

Cel. Celem badania było określenie zależności między postawami wobec wybranych rodzajów żywności i cechami socjodemograficznymi w grupie ludzi starszych, słuchaczy Uniwersytetu Trzeciego Wieku w Polsce.

Material i metody. Badania przeprowadzono wśród 607 słuchaczy Uniwersytetu Trzeciego Wieku z wykorzystaniem autorskiego kwestionariusza ankiety. Badanie było anonimowe. Określono postawy wobec walorów zdrowotnych żywności, żywności typu light i organicznej, nowej żywności, żywności jako nagrody i przyjemności, opakowania i składu produktu, jak też wobec ograniczeń w spożyciu żywności.

Wyniki. Zależności między postawami, a płcią, wiekiem, poziomem wykształcenia, aktywnością zawodową, wartością wskaźnika BMI i sytuacją ekonomiczną respondentów okazały się zróżnicowane. Pozytywne postawy (w ponad 50\%) odnotowano jedynie w odniesieniu do walorów zdrowotnych żywności oraz informacji na opakowaniu, a w przypadku pozostałych determinant dominowały postawy neutralne. Istotne zależności trzech postaw i cechy socjodemograficznej stwierdzono jedynie dla płci, zależności dwóch postaw od takiej cechy - dla aktywności zawodowej oraz statusu ekonomicznego, a zależność tylko jednej z postaw - jedynie dla wieku i wykształcenia.

Wnioski. Uzyskane wyniki można tłumaczyć złożonym efektem specyfiki badanej grupy i ogólnej tendencji do bardziej konserwatywnych postaw w starszym wieku. Wpływ płci na postawy jest najbardziej istotny, natomiast zależności między postawami względem żywności i pozostałymi cechami socjodemograficznymi nie są tak znaczące w badanej grupie słuchaczy Uniwersytetu Trzeciego Wieku.

Słowa kluczowe: postawy żywieniowe, osoby starsze, determinanty wyboru żywności, cechy socjodemograficzne

Corresponding author: Magdalena Tańska, Pomeranian University in Slupsk, Institute of Health Science, Westerplatte 64, Gdańsk, Poland, phone +48 503405 700, e-mail: magdalena.tanska@apsl.edu.pl

(c) Copyright by the National Institute of Public Health - National Institute of Hygiene 


\section{INTRODUCTION}

In all developed countries, because of quickly increasing average age and decreasing the number of children, the fractions of elderly people become greater. In the whole of Europe, the number of citizens aged 65+ is expected to account for over $30 \%$ of the population by 2050 [17].

A thorough understanding of the elderly people as food consumers, their nutritional needs, food perception, and preferences are necessary, for the aging societies, to increase or at least maintain the quality of life (QoL). The QoL is nowadays an essential term considered as subjective well-being, life satisfaction, or happiness [6]. For example, the relative (emotional) well-being results from an assessment of the environment, in which a person lives, his/her needs and desires, comparisons with other persons, and personal features influencing feelings of satisfaction and happiness [8].

The QoL perception is relatively stable during the whole mature life, but it decreases among elderly persons [6]. The QoL is influenced by a variety of determinants. Among them, the economic security and education level were assumed to affect life satisfaction [28]. In the research made on the subjects aged 18-65 yrs. [15] the most critical determinants of the QoL were good health, self-independence, good incomes, proper relations with family and friends, possessing a comfortable apartment or house, life satisfaction, pleasant neighborhood, the possibility of education. The elderly males declared better QoL than the females, and such people living with their families felt better than the lonely elderlies $[2,42]$.

The critical determinant of the QoL is the eating behavior and its anticipated relation with health. The health-related QoL was considered as the primary goal for health promotion [9]. The excellent nutrition would stimulate the health-related QoL by averting malnutrition, preventing dietary deficiency disease, and promoting optimal functioning [3]. When investigating the residents of long-term care facilities, their QoL related to eating was found positive, but issues related to autonomy such as food choice and snack availability were less favorable [33]. The proper nutritional status, diet quality, and sufficient protein and micronutrient intakes were essential for the health and well-being of elderly people [25].

An appearance of a relationship between nutritional status and QoL was noticed among people in malnutritional status [34]. Some of the food restrictions, such as avoiding fatty meat and dairy products, animal fats, sugar and sweets, salt and salted foods, were in line with recommendations to elderly people and could have beneficial effects on fat, salt, and sugar intake [54]. In Poland, such restrictions resulting in the improper eating behavior of elderly people were found $[27,66$,
67]. In particular, the shortage of fruit, raw vegetables, and milk, and excess intake of animal fat were frequent $[26,62,66]$. With increasing age, the feeling of hunger and thirst decreases, the feeling of taste and smell also decreases, and thus the meal consumption does not provide such pleasure as in younger and middle-aged resulting in unbalanced eating [38]. The reduction in food intake and the amount of liquid consumed occurs as a result of reduced appetite and thirst or inadequate consistency of the food that causes problems with chewing food [31]. The experience affects the views on foods and meals [13]. Even the frequency of feeding of many elderly people does not meet the needs of their organisms [18].

The studies of determinants of food attitudes in this group of persons were not frequent. The prohealth attitudes of some elderly people likely followed the advice of friends and the reading of popular science guides [5]. On the other hand, adherence to a healthy Baltic Sea diet (BSD) among Finnish elderly women was not related to their perception of $\mathrm{QoL}$ [49]. The neophobia, a less investigated phenomenon, was mostly influenced by the material situation and professional activity of elderly people [63]. Therefore, in this investigation, a specific group of elderly people, the students of the Third Age University (TAU), was surveyed. Such a group has been selected based on an assumption that it is composed of people relatively welleducated, ambitious, and active that may affect their food attitudes. The main determinants of the research were some socio-economic features.

\section{MATERIAL AND METHODS}

The survey was done in 2014 among 607 participants of the Third Age University in Pomerania and Western Pomerania voivodships in Poland based on the author's questionnaire. The survey was anonymous. The detailed characteristics of the sample are shown in Table 1.

The main study was followed by a pilot study to verify the correctness of the prepared questionnaire and to introduce some necessary changes. Here described study was composed of a collection of data on some sociodemographic determinants (gender, age, education level, professional activity, BMI index, and economic status of subjects) and assessed food attitudes.

The attitudes towards six different features of foods such as health benefits of foods, light and organic foods, novel foods, the food as a reward or as a pleasure, packaging together with the composition of food, and restrictions of food intake, were investigated. The relations of food attitudes on the above-mentioned determinants were assessed. The determinants were divided into two, three, or four levels.

The attitudes were determined by the appropriate following survey tests, already used or here developed: 
Table 1. Characteristics of the sample in the study

\begin{tabular}{|c|c|c|}
\hline $\begin{array}{c}\text { Socio-demographic } \\
\text { determinants }\end{array}$ & Description & Percentage \\
\hline \multirow{2}{*}{ Gender } & Males & 82.4 \\
\hline & Females & 17.6 \\
\hline \multirow{3}{*}{ Age (years) } & $<60$ & 16.0 \\
\hline & $61-70$ & 51.7 \\
\hline & $70+$ & 32.3 \\
\hline \multirow{3}{*}{ Education level } & Primary & 11.5 \\
\hline & Secondary & 52.4 \\
\hline & Higher & 36.1 \\
\hline \multirow{2}{*}{ Professional activity } & Active & 23.4 \\
\hline & Inactive & 76.6 \\
\hline \multirow{4}{*}{$\begin{array}{l}\text { BMI index value } \\
\left(\mathrm{kg} / \mathrm{m}^{2}\right)\end{array}$} & $<20$ & 0.5 \\
\hline & $20-25$ & 38.2 \\
\hline & $25-30$ & 43.7 \\
\hline & $>30$ & 17.6 \\
\hline \multirow{4}{*}{ Economic status } & Very good & 9.6 \\
\hline & Moderate & 81.4 \\
\hline & $\mathrm{Bad}$ & 7.4 \\
\hline & Very bad & 1.6 \\
\hline
\end{tabular}

- Health Attitude Scale [47] for an assessment of attitudes towards the health benefits of foods ( 8 statements)

- Natural Food Product Attitude Scale [47] for an assessment of attitudes towards the light and organic foods (6 statements)

- Food Neophobia Scale [46] for an assessment of attitudes towards novel foods (6 statements selected by the authors)
- Using Food as a Reward and Pleasure Scale [48] for an assessment of attitudes towards the food as a prize or as a pleasure (6 statements)

- Attitude Scale for an assessment of attitudes towards the information on the packaging (4 statements; developed by the authors)

- Restricted Eating Scale [65] for an assessment of attitudes towards the restriction of food intake (6 statements )

The Likert Scale was applied to measure attitudes. The testresults were analyzed using the Microsoft Office Excel 97-2003 for Windows spreadsheet function and Statistica version 7. Evaluation of attitudes containing analyzed statements was carried out using the 5-point scale, beginning from 1 (disagree), 2 (rather disagree), 3 (neither agree nor disagree), 4 (rather agree), and 5 (agree). The attitude was assumed as positive if the received value was 5 or 4 , negative for 1 and 2, and neutral for value 3 .

A Chi-square test was used to test the significance of relations between determinants and attitudes. The probability levels show the values at which the statement about no appearance of a significant relationship between a determinant and attitude (positive, negative, or neutral) is true.

\section{RESULTS}

The results of investigations are shown in Figure 1 for the whole sample and in Tables 2-7 as relations between different determinants and attitudes. The positive attitudes over $50 \%$ were noticed only for two attitudes, on the health benefits of foods, and the

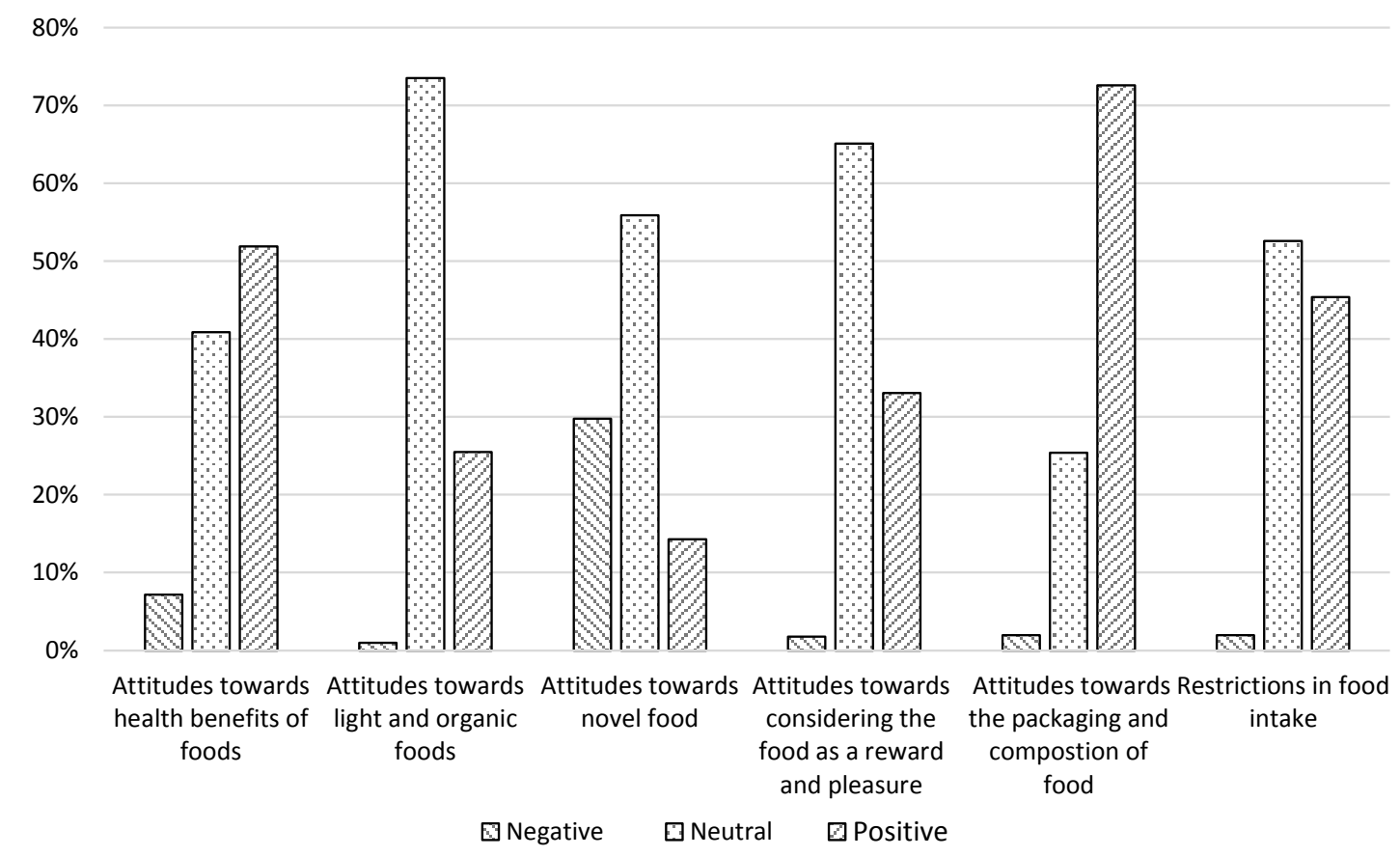

Figure1. Percentage of subjects expressing their negative, positive or neutral attitudes towards some foods 
packaging and composition of the food. For other attitudes the neutral attitudes were dominant.

As considering gender (Table 2), there was a significant relation of three attitudes on this determinant, namely towards the health benefits, foods as a reward or pleasure, and the packaging and composition of the food. Females more often than males indicated the importance of the health benefits, the food offered as a reward or as pleasure, and the packaging and composition of the food.
Age was an important determinant of food attitudes only as regards the packaging and composition of food (Table 3). The appearance of this positive attitude was negatively correlated with age.

The significant relations were also observed for education level as a determinant (Table 4). However, the relations between education level and different attitudes were relatively inconsistent.

Table 2. Attitudes of participants as related to gender (in pct. of the sample)

\begin{tabular}{|c|c|c|c|c|}
\hline \multirow{2}{*}{ Attitude } & \multirow{2}{*}{ Gender } & \multicolumn{3}{|c|}{ Attitude } \\
\hline & & Negative & Neutral & Positive \\
\hline \multirow{2}{*}{$\begin{array}{l}\text { Attitude towards health benefits of foods } \\
p=0.0010^{*}\end{array}$} & Females & 1.6 & 26.6 & 71.8 \\
\hline & Males & 8.4 & 43.9 & 47.7 \\
\hline \multirow{2}{*}{$\begin{array}{l}\text { Attitude towards light and organic foods } \\
p=0.2100\end{array}$} & Females & 1.2 & 71.8 & 27.0 \\
\hline & Males & 0.9 & 73.8 & 25.2 \\
\hline \multirow{2}{*}{$\begin{array}{l}\text { Attitude towards novel food } \\
p=0.2100\end{array}$} & Females & 33.2 & 55.4 & 11.4 \\
\hline & Males & 29.0 & 56.1 & 15.0 \\
\hline \multirow{2}{*}{$\begin{array}{l}\text { Attitude towards the food as a reward and } \\
\text { pleasure } \\
p=0.0002 *\end{array}$} & Females & 0.4 & 59.6 & 40.0 \\
\hline & Males & 1.9 & 66.4 & 31.8 \\
\hline \multirow{2}{*}{$\begin{array}{l}\text { Attitude towards packaging and composition of } \\
\text { the food } \\
p=0.0070^{*}\end{array}$} & Females & 1.4 & 13.2 & 85.4 \\
\hline & Males & 1.9 & 28.0 & 70.1 \\
\hline \multirow{2}{*}{$\begin{array}{l}\text { Attitude towards restrictions in food intake } \\
p=0.8900\end{array}$} & Females & 1.4 & 49.4 & 49.2 \\
\hline & Males & 1.8 & 53.3 & 44.9 \\
\hline
\end{tabular}

Table 3. Attitudes of participants as related to age (in pct. of the sample)

\begin{tabular}{|c|c|c|c|c|}
\hline Attitude & Age (years) & Negative & Neutral & Positive \\
\hline \multirow{3}{*}{$\begin{array}{l}\text { Attitude towards health benefits of foods } \\
p=0.4800\end{array}$} & $51-60$ & 2.3 & 32.6 & 65.1 \\
\hline & $61-70$ & 3.2 & 24.5 & 72.3 \\
\hline & $70+$ & 2.6 & 35.2 & 62.2 \\
\hline \multirow{3}{*}{$\begin{array}{l}\text { Attitude towards light and organic foods } \\
p=0.1100\end{array}$} & $51-60$ & 0.0 & 66.3 & 33.7 \\
\hline & $61-70$ & 1.0 & 74.8 & 24.2 \\
\hline & $70+$ & 2.0 & 69.9 & 28.1 \\
\hline \multirow{3}{*}{$\begin{array}{l}\text { Attitude towards novel food } \\
p=0.1040\end{array}$} & $51-60$ & 22.1 & 69.8 & 8.1 \\
\hline & $61-70$ & 30.3 & 55.4 & 14.3 \\
\hline & $70+$ & 42.3 & 49.0 & 8.7 \\
\hline \multirow{3}{*}{$\begin{array}{l}\text { Attitude towards considering the food as a } \\
\text { reward and pleasure } \\
p=0.0700\end{array}$} & $51-60$ & 0.0 & 58.1 & 41.9 \\
\hline & $61-70$ & 1.0 & 59.9 & 39.2 \\
\hline & $70+$ & 0.5 & 61.2 & 38.3 \\
\hline \multirow{3}{*}{$\begin{array}{l}\text { Attitude towards the packaging and } \\
\text { composition of the food } \\
p=0.0000^{*}\end{array}$} & $51-60$ & 0.0 & 14.0 & 86.0 \\
\hline & $61-70$ & 0.6 & 13.4 & 86.0 \\
\hline & $70+$ & 3.6 & 21.4 & 75.0 \\
\hline \multirow{3}{*}{$\begin{array}{l}\text { Restrictions in food intake } \\
p=0.4200\end{array}$} & $51-60$ & 0.0 & 46.5 & 53.5 \\
\hline & $61-70$ & 1.6 & 48.4 & 50.0 \\
\hline & $70+$ & 2.0 & 54.1 & 43.9 \\
\hline
\end{tabular}


The professional activity (Table 5) was a significant determinant of the attitudes towards the novel food and the packaging and composition of the food. On the other side, these relations were relatively weak.

The BMI value was a significant determinant also for two attitudes (Table 6), towards the health benefits and the novel foods. The positive attitudes followed the increasing BMI value.
For the last determinant, the economic status (Table 7), it became important for three attitudes, namely towards the novel food, the food as a reward and pleasure, and the packaging and food composition. However, the relations of these attitudes on economic status were complex.

Table 4. Attitudes of participants as related to education level (in pct. of the sample)

\begin{tabular}{|c|c|c|c|c|}
\hline Attitude & Education level & Negative & Neutral & Positive \\
\hline \multirow{3}{*}{$\begin{array}{l}\text { Attitude towards health benefits of foods } \\
p=0.1300\end{array}$} & Primary & 0.0 & 39.1 & 60.9 \\
\hline & Secondary & 2.8 & 23.0 & 74.2 \\
\hline & Higher & 3.7 & 36.1 & 60.3 \\
\hline \multirow{3}{*}{$\begin{array}{l}\text { Attitude towards light and organic foods } \\
p=0.6600\end{array}$} & Primary & 0.0 & 68.9 & 31.1 \\
\hline & Secondary & 1.9 & 69.8 & 28.3 \\
\hline & Higher & 0.5 & 76.3 & 23.3 \\
\hline \multirow{3}{*}{$\begin{array}{l}\text { Attitude towards novel food } \\
p=0.2900\end{array}$} & Primary & 43.5 & 44.3 & 12.2 \\
\hline & Secondary & 32.1 & 57.9 & 10.1 \\
\hline & Higher & 30.1 & 55.3 & 14.6 \\
\hline \multirow{3}{*}{$\begin{array}{l}\text { Attitude towards considering the food as a } \\
\text { reward and pleasure } \\
p=0.1500\end{array}$} & Primary & 0.0 & 67.8 & 32.2 \\
\hline & Secondary & 1.3 & 59.4 & 39.3 \\
\hline & Higher & 0.0 & 60.7 & 39.3 \\
\hline \multirow{3}{*}{$\begin{array}{l}\text { Attitude towards the packaging and } \\
\text { composition of the food } \\
p=0.0100^{*}\end{array}$} & Primary & 2.6 & 15.4 & 82.0 \\
\hline & Secondary & 1.6 & 14.8 & 83.6 \\
\hline & Higher & 0.9 & 17.4 & 81.7 \\
\hline \multirow{3}{*}{$\begin{array}{l}\text { Restrictions in food intake } \\
p=0.0600\end{array}$} & Primary & 0.2 & 75.9 & 23.9 \\
\hline & Secondary & 3.0 & 44.9 & 52.1 \\
\hline & Higher & 0.0 & 57.9 & 42.1 \\
\hline
\end{tabular}

Table 5. Attitudes of participants as related to professional activity (in pct. of the sample)

\begin{tabular}{|c|c|c|c|c|}
\hline Attitude & $\begin{array}{l}\text { Professional } \\
\text { activity }\end{array}$ & Negative & Neutral & Positive \\
\hline \multirow{2}{*}{$\begin{array}{l}\text { Attitude towards health benefits of foods } \\
p=0.2800\end{array}$} & Active & 4.9 & 35.2 & 59.9 \\
\hline & Inactive & 2.2 & 28.0 & 69.9 \\
\hline \multirow{2}{*}{$\begin{array}{l}\text { Attitude towards the light and organic foods } \\
p=0.7200\end{array}$} & Active & 0.7 & 69.7 & 29.6 \\
\hline & Inactive & 1.3 & 72.9 & 25.8 \\
\hline \multirow{2}{*}{$\begin{array}{l}\text { Attitude towards novel food } \\
p=0.0130^{*}\end{array}$} & Active & 23.2 & 64.1 & 12.7 \\
\hline & Inactive & 35.3 & 52.9 & 11.8 \\
\hline \multirow{2}{*}{$\begin{array}{l}\text { Attitude towards considering food as a reward } \\
\& \text { pleasure } \\
p=0.0900\end{array}$} & Active & 0.7 & 61.3 & 38.0 \\
\hline & Inactive & 0.6 & 60.6 & 38.7 \\
\hline \multirow{2}{*}{$\begin{array}{l}\text { Attitude towards packaging and composition of } \\
\text { the food } \\
p=0.0370^{*}\end{array}$} & Active & 0.7 & 14.1 & 85.2 \\
\hline & Inactive & 1.7 & 16.3 & 81.9 \\
\hline \multirow{2}{*}{$\begin{array}{l}\text { Restrictions in food intake } \\
p=0.3200\end{array}$} & Active & 2.1 & 50.7 & 47.2 \\
\hline & Inactive & 1.3 & 49.9 & 48.8 \\
\hline
\end{tabular}


Table 6. Attitudes of participants as related to the BMI value (in pct. of the sample)

\begin{tabular}{|c|c|c|c|c|}
\hline Attitude & $\begin{array}{c}\mathrm{BMI} \\
\left(\mathrm{kg} / \mathrm{m}^{2}\right) \\
\end{array}$ & Negative & Neutral & Positive \\
\hline \multirow{4}{*}{$\begin{array}{l}\text { Attitude towards health benefits of foods } \\
p=0.0060^{*}\end{array}$} & $<20$ & 0.0 & 66.7 & 33.3 \\
\hline & $20-25$ & 1.3 & 30.2 & 68.5 \\
\hline & $25-30$ & 3.4 & 29.4 & 67.2 \\
\hline & $>30$ & 4.7 & 28.0 & 67.3 \\
\hline \multirow{4}{*}{$\begin{array}{l}\text { Attitude towards light and organic foods } \\
p=0.3900\end{array}$} & $<20$ & 0.0 & 100.0 & 0.0 \\
\hline & $20-25$ & 0.9 & 73.7 & 25.4 \\
\hline & $25-30$ & 0.8 & 74.3 & 24.9 \\
\hline & $>30$ & 2.8 & 62.6 & 34.6 \\
\hline \multirow{4}{*}{$\begin{array}{l}\text { Attitude towards novel food } \\
p=0.0050^{*}\end{array}$} & $<20$ & 33.3 & 66.7 & 0.0 \\
\hline & $20-25$ & 33.6 & 56.9 & 9.5 \\
\hline & $25-30$ & 32.8 & 58.1 & 9.1 \\
\hline & $>30$ & 29.0 & 45.8 & 25.2 \\
\hline \multirow{4}{*}{$\begin{array}{l}\text { Attitude towards considering the food as a } \\
\text { reward and pleasure } \\
p=0.8000\end{array}$} & $<20$ & 0.0 & 100.0 & 0.0 \\
\hline & $20-25$ & 0.4 & 57.3 & 42.2 \\
\hline & $25-30$ & 0.4 & 62.3 & 37.4 \\
\hline & $>30$ & 1.9 & 63.6 & 34.6 \\
\hline \multirow{4}{*}{$\begin{array}{l}\text { Attitude towards the packaging and } \\
\text { composition of the food } \\
p=0.5900\end{array}$} & $<20$ & 0.0 & 0.0 & 100.0 \\
\hline & $20-25$ & 2.6 & 18.5 & 78.9 \\
\hline & $25-30$ & 0.4 & 14.0 & 85.7 \\
\hline & $>30$ & 1.9 & 15.0 & 83.2 \\
\hline \multirow{4}{*}{$\begin{array}{l}\text { Restrictions in food intake } \\
p=0.0600\end{array}$} & $<20$ & 0.0 & 100.0 & 0.0 \\
\hline & $20-25$ & 0.4 & 51.7 & 47.8 \\
\hline & $25-30$ & 3.0 & 44.9 & 52.1 \\
\hline & $>30$ & 0.0 & 57.9 & 42.1 \\
\hline
\end{tabular}

Table 7. Attitudes of participants as related to economic status (in pct. of the sample)

\begin{tabular}{|c|c|c|c|c|}
\hline Attitude & $\begin{array}{l}\text { Economic } \\
\text { status }\end{array}$ & Negative & Neutral & Positive \\
\hline \multirow{4}{*}{$\begin{array}{l}\text { Attitude towards health benefits of foods } \\
p=0.5900\end{array}$} & Very good & 0.0 & 22.4 & 77.6 \\
\hline & Moderate & 3.2 & 30.0 & 66.8 \\
\hline & $\mathrm{Bad}$ & 0.0 & 35.6 & 64.4 \\
\hline & Very bad & 10.0 & 30.0 & 60.0 \\
\hline \multirow{4}{*}{$\begin{array}{l}\text { Attitude towards light } \\
\text { and organic foods } \\
p=0.4900\end{array}$} & Very good & 6.9 & 69.0 & 24.1 \\
\hline & Moderate & 0.4 & 72.9 & 26.7 \\
\hline & $\mathrm{Bad}$ & 2.2 & 73.3 & 24.4 \\
\hline & Very bad & 0.0 & 50.0 & 50.0 \\
\hline \multirow{4}{*}{$\begin{array}{l}\text { Attitude towards novel food } \\
p=0.0010^{*}\end{array}$} & Very good & 32.8 & 48.3 & 19.0 \\
\hline & Moderate & 32.2 & 56.1 & 11.7 \\
\hline & $\mathrm{Bad}$ & 42.2 & 57.8 & 0.0 \\
\hline & Very bad & 0.0 & 60.0 & 40.0 \\
\hline \multirow{4}{*}{$\begin{array}{l}\text { Attitudes towards considering the food as a } \\
\text { reward and pleasure } \\
p=0.0300^{*}\end{array}$} & Very good & 0.0 & 60.3 & 39.7 \\
\hline & Moderate & 0.8 & 60.7 & 38.5 \\
\hline & $\mathrm{Bad}$ & 0.0 & 68.9 & 31.1 \\
\hline & Very bad & 0.0 & 30.0 & 70.0 \\
\hline \multirow{4}{*}{$\begin{array}{l}\text { Attitude towards the packaging and compo- } \\
\text { sition of the food } \\
\mathrm{p}=0.0000^{*}\end{array}$} & Very good & 1.7 & 10.3 & 87.9 \\
\hline & Moderate & 0.8 & 15.6 & 83.6 \\
\hline & $\mathrm{Bad}$ & 8.9 & 20.0 & 71.1 \\
\hline & Very bad & 0.0 & 40.0 & 60.0 \\
\hline \multirow{4}{*}{$\begin{array}{l}\text { Restrictions in food intake } \\
p=0.0600\end{array}$} & Very good & 0.0 & 43.1 & 56.9 \\
\hline & Moderate & 1.8 & 49.8 & 48.4 \\
\hline & $\mathrm{Bad}$ & 0.0 & 64.4 & 35.6 \\
\hline & Very bad & 0.0 & 40.0 & 60.0 \\
\hline
\end{tabular}




\section{DISCUSSION}

\section{The attitudes towards health importance}

The attitudes measured in the sample composed of participants of the TAU, a particular social group, towards various aspects of eating behavior, ranged between negative through neutral up to positive ones, depending on the specific attitude and determinant. The positive attitudes were expressed by over $50 \%$ of subjects only towards the health benefits of food. This result is in perfect accordance with several previous reports in which good health was considered essential for the Polish people [21, 22, 29, 32, 35, 55, 58]. It may be assumed that the positive attitudes of the elderly people towards the health-related diet can result from the willingness to consume products that positively affect the health of seniors. Such supposition is confirmed by the frequent occurrence of many illnesses and an appearance of beliefs in prohealth diets, like cholesterol-lowering products, often consumed by people aged $50+[10,24,61,66]$. The coronary diseases are typical for elderly persons and are associated often with their eating [11, 12]. Diseases of the gastrointestinal tract occur frequently among people aged 65+ in many European countries [23] and include the gastro-oesophageal reflux disease for 53 $66 \%$ of respondents, cholelithiasis for about $30 \%$ of females, and $16-20 \%$ of males, and the diseases of the large intestine constitute about $25 \%$ of all diseases typical for the elderly people. Numerous diseases and drug intake increase the risk of adverse interactions and enforce modifications in the nutrition of the elderly persons, and limit the free choice of food [16]. Every third inhabitant of Poland complained about long-term health problems or chronic diseases lasting at least six months, almost $60 \%$ of people aged $50+$ and $73 \%$ of those aged $60+$ [57]. On the other hand, expected increased mental or physical activity of any type [14] can be a reason for coming people to the TAU. The health consciousness was a stimulus that positively affects the eating facilitators (natural content, nutritional content, and ecological welfare) as well as inhibitors (usage, risk, and value barriers) [59]. Such behavior can be even unconscious; in previous research, only a few participants met the recommendations for the different food [19].

\section{The attitudes towards light and organic food}

There are not too many studies on the relationships between the elderlies' attitudes towards light products and organic food. Participation in cultural activities had a positive impact on the inclination to purchase organic products, to an extent dependent on the social orientation of each cultural activity [1]. Moreover, higher organic budget shares were found among welleducated consumers in urban areas and linked to the belief that organic products are healthier. On the other hand, no significant relations were determined between the consumption of organic food and the perceptions that organic products were more animal or environmentally friendly [7]. On the other hand, the perception of foods suitable for weight management like light foods rested not only on simple measures such as energy, fat, and sugar but also on a complex set of generalized food ideals [41].

\section{The attitudes towards the novel food}

Even if neutral attitudes are characteristic of many foods, the most diversified become attitudes towards the novel food. The negative attitudes were expressed by about $30 \%$ of the sample and, simultaneously, the positive ones were prevalent. It means that elderly people do not remain neutral against novel foods. Attitudes towards novel foods can be significantly different, and their extreme forms are referred to as nutritional neophobia (negative attitude) and food neophilia (positive attitude). In an earlier study, $82 \%$ of subjects declared that they preferred already known food and only $23 \%$ chose the exotic dishes [63]. In other work by Jeżewska-Zychowicz et al. [24], the low nutritional neophobia was observed among professionally active people. Current research also showed that the negative attitude towards novel food was expressed mainly by people with only primary education. Along with the increase in education, a smaller percentage of people with high food neophobia and at the same time a higher percentage of people with low food neophobia were found. Similarly, the convenience food was also accepted by elderly people in other research [45]. The associations between food security, the most uncertain for novel foods, and health outcomes are characteristic in older adults [43]. The elderly may be more willing to accept novel foods than do younger adults because of olfaction [44]. The food history, sensory and oral motors can be important determinants in the food choice [51]. However, in Song et al. studies [53], the older consumers were shown to be the most determined to purchase and try healthy, but traditional meal component foods enriched with protein. On the other hand, Jeżewska-Zychowicz et al. [24] also proved that the elderly people declared the most frequently among all that they neither knew nor took the novel food.

\section{The attitudes towards the food as a reward or pleasure}

Nutritional behaviors are not always the answer to the feeling of hunger as the emotions and mood often condition them. The participants of the TAU scarcely expressed a negative attitude in this case. The high support for such attitude was observed among females, which may result from the greater emotionality of 
women trying to improve their mood, for example by eating sweets often resulting in overweight [37]. The subjective hedonic experience of food is certainly encoded in the area of activity in the pleasure system [30]. For persons aged 65-101 yrs., the tendency to prefer sweet and solid food was already noticed and this specific desire disappeared at hospitalized patients or retirement houses residents [64]. Another case is a long-term treatment of people with obesity who after at least 5 months stopped to consider the food as a reward [39]. The pleasure motivation was observed as a stronger predictor of eating than demographic factors people aged at 65+ in Australia [52].

\section{The attitudes towards the packaging and food composition}

The attitudes of the elderly people expressed towards the packaging and food composition of the product are often significant. The product label is essential information about the food and affects its acceptance and choice. The statistical significance between attaching attention to the information on the packaging (label) by the respondents was shown, and age, the level of education, and professional activity of seniors were important as the determinants. Similar results were already obtained by Niewczas [40], demonstrating the significant impact of specific information on the packaging on the perception to the extent related to food, age, gender, and education level. So far reports on a relationship between diet and food label indicated that reading the nutrition facts label was associated with healthier diets [4]. Frontof-pack labeling was a particularly efficient tool for increasing consumers' awareness of the nutritional quality of food products and promoting healthier food choices [50]. The importance of labeling and quality of information was noticed in several reports [60], particularly as concerns the contents of specific supplements. Moreover, some consumers are willing to pay a premium for redundant or superfluous food labels that carry no additional information for the informed consumer [68]. Finally, it is interesting that hungering for the past which may be frequent among elderlies together with nostalgic food labels may increase purchase intentions and actual consumption [69].

\section{The attitudes towards food restrictions}

The diet restrictions are well accepted and they are then in full accordance with previous studies. The investigations of elderly people, residents of the Warsaw neighborhood, showed that over $67 \%$ of subjects applied food restrictions and 33\% introduced fresh vegetables and fruit, yogurts, wholemeal bread, low-fat meat and cold cuts, fruit and vegetable juices to their diets for health reasons. According to Wierzbicka and Roszkowski [67], only $10 \%$ of elderly people avoid fruit, vegetables, and milk. Such attitudes may be due to the real needs of elderlies who suffer from different illnesses or obesity. However, tooth loss and the lack of oral rehabilitation certainly results in the restriction of the consumption of fruits, vegetables, proteins, as shown in Brasil among people aged 65-74 [56].

\section{Summary}

Considering the possible relations between sociodemographic determinants and attitudes, the effect of gender was here the most prevalent as noticed in many past studies $[24,36]$. Other determinants, like age, education level, professional activity, economic status, and BMI value affected only slightly some of the attitudes, and usually in a complex manner. However, the economic security and education level can influence the life satisfaction of the people [20, 28]. Such determinants did not seriously differentiate the eating attitudes observed in this study likely because the subjects were relatively well-educated and active in the TAU, imagined themselves as being in good or perfect economic situation. That confirming, Jeżewska-Zychowicz et al. [24] observed a similar lack of relationship between the level of education and professional activity and the consumption of prohealth food.

\section{CONCLUSIONS}

Results of the studies showed a limited number of statistically significant correlations between the attitudes of the elderly people, participants of the TAU, and the examined sociodemographic features. Gender seems the essential determinant of food attitudes when compared to all other determinants. The reasons may be the different meanings of the quality of life and different experiences of surveyed elderlies, and various roles of elderly males and females in society.

The most positive attitude is expressed towards health benefits. Such behavior is entirely justified by a sample of elderly adults suffering from different illnesses.

A high fraction of neutral attitudes may result from different reasons for each attitude: lack of interest in light and organic foods or in considering the food as a reward or pleasure, typical of elderly people.

\section{Conflict of interest}

The authors declare no conflict of interest.

\section{REFERENCES}

1. Agovino M., Crociata A., Quaglione D., Sacco P., Sarra A.: Good Taste Tastes Good. Cultural Capital as a Determinant of Organic Food Purchase by Italian 
Consumers: Evidence and Policy Implications. Ecol Econ 2017;141:66-75.

2. Al Windi A., Elmfeldt D., Tibblin G., Svärdsudd K.: The influence of sociodemographic characteristics on wellbeing and symptoms in a Swedish community. Results from a postal questionnaire survey. Scand J Prim Health Care 1999;17:201-209.

3. Amarantos E., Martinez A., Dwyer J.: Nutrition and quality of life in older adults. J Gerontol A Biol Sci Med Sci 2001; 56, No. 2, 54-64.

4. Anastasiou K., Miller M., Dickinson K.: The relationship between food label use and dietary intake in adults: A systematic review. Appetite 2019;138:280-291.

5. Babicz-Zielińska E, Tańska M.: Rola Uniwersytetu Trzeciego Wieku w kształtowaniu prozdrowotnych postaw słuchaczy [The role of the University of the Third Age in shaping pro health attitudes of its students]. Marketing i rynek, Konsumpcja i Innowacje. Wyd. IBRiK, 2015; 211-219 (in Polish).

6. Bowling A.: Ageing Well. Quality of life in old age. London, UK, McGraw-Hill Educ. 2005.

7. Denver S., Christensen T.: Organic food and health concerns: a dietary approach usingobserved data. NJAS Wageningen J Life Sci 2015;74-75:9-15.

8. Diener E., Lucas R.E., Oishi S., Suh E.M.: Looking up and looking down: Weighting good and bad information in life satisfaction judgments. Pers Soc Psychol Bull 2002; 28: 437-445.

9. Drewnowski A, Evans W.J.: Nutrition, physical activity, and quality of life in older adults: summary. J Gerontol A Biol Sci Med Sci 2001; 56, No. 2, 89-94.

10.Drewnowski A., Shultz J.M.: Impact of aging on eating behaviors, food choices, nutrition, and health status. J Nutr Health Aging 2001;5(2):75-9.

11. Duda G.: Zwyczaje żywieniowe a stan zdrowia i odżywienia osób w wieku podeszłym [Eating habits in relation to health and nutrition of the elderly]. Brom Chem Toksykol 2003; suppl:243-248 (in Polish).

12.Duda G., Jóźwiak A., Chmielewska Z.: Wybrane elementy stylu życia i nieprawidłowości stanu odżywienia osób w wieku podeszłym $\mathrm{z}$ niedokrwienną chorobą serca. Badania wstępne [Selected aspects of lifestyle and nutritional abnormalities of elderly people with ischemic heart disease. Preliminary studies]. Now Lek 2001; 70: 1028-1036 (in Polish).

13. Edfors E., Westergren A.: Home-living elderly people's views on food and meals. J Aging Res 2012; (3):761291.

14. Feng T., Feng Z., Jiang L., Yu Q., Liu K.: Associations of health behaviors, food preferences, and obesity patterns with the incidence of mild cognitive impairment in the middle-aged and elderly population: An 18-year cohort study. J Affective Disorders 2020;275:180-186.53

15.Fernandez-Ballesteros R.F.: GeroPsychology. An Applied Field for the $21^{\text {st }}$ Century. Europ Psych 2006; 11, 4: 312-323.

16. Gębska-Kuczerowska A., Miller M.: Sytuacja zdrowotna ludzi powyżej 65 roku życia [The health situation adults 65 years and older]. Zdrowie Publ 2006; 16(1):135-137 (in Polish).
17. Giacalone D., Wendin K., Kremer S., Bom Frøst M., Wender L.P., Bredie W.L.P., Olsson V., Otto M.H., Skjoldborg S., Lindberg U., Risvik E.: Health and quality of life in an aging population - Food and beyond. Food Qual Pref 2016; 47, B, 166-170.

18. Gibney M.J., Margetts B.M., Kearney J.M., Arab L.: Public health nutrition. Oxford, Blackwell Science 2004.

19. Gille D., Bütikofer U., Chollet M., Schmid A., Altintzoglou T., Honkanen P., Stoffers H., Walther B., Piccinali P.: Nutrition behavior of the middle-aged and elderly: Compliance with dietary recommendations of the food pyramid. Clinic Nutr 2016;35:638-644.

20.Głębocka A., Szarzyńska M.: Wsparcie społeczne a jakość życia ludzi starszych [Social support and quality of life in older adults]. Gerontol Pol 2005;3(4):255-259 (in Polish).

21. Halicka M.: Satysfakcja życiowa ludzi starych [Life satisfaction of the elderly]. Białystok, Akademia Medyczna w Białymstoku 2004 (in Polish).

22.Halicka M., Pędzich W.: Satysfakcja życiowa ludzi starych [Life satisfaction of the elderly]. In: Synak B. eds. Polska starość [Polish old age]. Gdańsk, Wydawnictwo Uniwersytetu Gdańskiego 2002 (in Polish).

23.Jarosz M., Sajor I.: Sytuacja demograficzna w Polsce i na Świecie ze szczególnym uwzględnieniem osób w wieku starszym [The demographic situation in Poland and in the world with particular emphasis on the elderly. Nutrition of older adults]. In: Jarosz M. eds. Żywienie osób w wieku starszym [Nutrition of older adults]. Warszawa, Wydawnictwo Lekarskie PZWL 2011 (in Polish).

24.Jeżewska-Zychowicz M., Babicz-Zielińska E., Laskowski W.: Konsument na rynku nowej żywności [Consumer in the market of novel food]. Warszawa, Wydawnictwo SGGW 2009 (in Polish).

25. Jyväkorpi S.: Nutrition of older people and the effect of nutritional interventions on nutrient intake, diet quality and quality of life. Ph. D. Thesis, Univ. Helsinki 2016.

26.Kałuża J., Brzozowska A.: Wykorzystanie analizy włosów do oceny uwarunkowań stanu odżywienia żelazem osób starszych zamieszkałych w rejonie warszawskim [Use of hair analysis to assess the condition of iron nutrition of elderly people in the Warsaw region]. Żyw Czł Met 2002;29:294-298 (in Polish).

27. Kałuża J., Jeruszka M., Brzozowska A.: Ocena stanu odżywienia żelazem, cynkiem i miedzią osób starszych zamieszkałych w rejonie warszawskim na podstawie analizy włosów [Assessment of iron, zinc, and copper nutritional status of elderly residents of the Warsaw region on the basis of hair analysis]. Rocz Panstw Zakl Hig 2001;52:111-118 (in Polish).

28.Knurowski T., van Dijk J.P., Geckova A.M., Brzyski P., Tobiasz-Adamczyk B., van den Heuvel W.J.: Socio-economic health differences among the elderly population in Krakow, Poland. Sozial Präventivmed 2005;50:177-185.

29. Kozirok W., Baumgart A., Babicz-Zielińska E.: Postawy i zachowania konsumentów wobec żywności 
prozdrowotnej [Consumer attitudes and behaviours towards healthy foods]. Brom Chem Toksykol 2012;3:1030-1034 (in Polish).

30.Kringelbach M.L.: The pleasure of food: underlying brain mechanisms of eating and other pleasures. Flavour 2015;4:20.

31.Larrieu S., Letenneur L., Berr C., Dartigues J.F., Ritchie K., Alperovitch A., Tavernier B., BarbergerGateau P.: Sociodemographic differences in dietary habits in a population-based sample of elderly subjects. J Nutr Health Aging 2004;8:497-502.

32.Lassota L.: Satysfakcja $\mathrm{z}$ życia emerytów w Polsce i w Niemczech [Life satisfaction of pensioners in Poland and Germany. Ageing in relation to life satisfaction]. In: Steuden S., Marczuk M. eds. Starzenie się a satysfakcja $\mathrm{z}$ życia [Ageing in relation to life satisfaction]. Lublin, Wyd. Uniw. Lub. 2006 (in Polish).

33. Lengyel C.O., Zello G.A., Berenbaum S.L., Henry C.J., Whiting S.J.: A Model for Food Service Delivery and Quality of Life in Long-Term Care Facilities. In: Sirgy M.J., Rahtz D., Samli A.C. eds. Advances in Quality-ofLife Theory and Research. Social Indicators Research Series, Vol. 20. Dordrecht, Springer 2003.

34.Luger E., Haider S., Kapan A., Schindler K., Lackinger C., Dorner T.E.: Association between nutritional status and quality of life in (pre)frail community-dwelling older persons persons. J Frailty Aging 2016;5(8):suppl.3.

35. Maciejasz M., Timoszuk S., Eątkowski W., Grudecka A.: Wybrane aspekty życia osób w Polsce w świetle badań jakościowych. Studia Ekonomiczne [Selected aspects of people's lives in Poland in the context of qualitative research]. Zesz Nauk UEK 2015;223:257-267. (in Polish).

36. Marino M., Masella R., Bulzomi P., Campesi I., Malorni $W$., Franconi F.: Nutrition and human health from a sexgender perspective. Molec Aspects Medic 2001;32:1-70.

37. Marszat-Wiśniewska M., Nowicka M.: Temperamentalne uwarunkowania regulacji nastroju [Temperamental mood control factors]. Studia Psych 2007;45:63-72 (in Polish).

38. Maynard M., Gunnell D., Ness A.R., Abraham L., Bates C.J., Blane D.: What influences diet in early old age? Prospective and cross-sectional analyses of the Boyd Orr cohort. Eur J Public Health 2005;16(3):315-323.

39. Miguet M., Beaulieu K., Fillon A., Khammassi M., Masurier J., Lambert C., Duclos M., Boirie Y., Finlayson G., Thivel D.: Effect of a 10-month residential multidisciplinary weight loss intervention on food reward in adolescents with obesity. Physiol Behav 2020;223:112996.

40.Niewczas M.: Kryteria wyboru żywności [Food selection criteria]. Żywność Nauka Technol Jakość 2013;91:204-219 (in Polish).

41. Niva M., Jauho M., Mäkelä J.: "If I drink it anyway, then I rather take the light one". Appropriation of foods and drinks designed for weight management among middle-aged and elderly Finns. Appetite 2013;64:12-19.

42. Okła W.: Psychospołeczne uwarunkowania jakości życia osób starszych $\mathrm{w}$ rodzinach własnych i domach opieki społecznej [Psychosocial determinants of the quality of life of older adults in their own families and care homes. Ageing versus life satisfaction]. In: Steuden S., Marczuk M. eds. Starzenie się a satysfakcja z życia [Ageing in relation to life satisfaction]. Lublin, wyd. KUL 2006 (in Polish).

43.Pak T.-Y., Kim G.S.: Food stamps, food insecurity, and health outcomes among elderly. Amer Prev Medic 2020;130:105871.

44.Pelchat M.L.: You can teach an old dog new tricks: olfaction and responses to novel foods by the elderly. Appetite 2000;35:153-160.

45.Peura-Kapanen L., Jallinoja P., Kaarakainen M.: Acceptability of Convenience Food Among Older People, SAGE Open, January-March 2017:1-11. DOI: $10.1177 / 2158244017698730$.

46.Pliner P., Hobden K.: Development of a Scale to Measure the Trait of Food Neophobia in Humans. Appetite 1992;19:105-120.

47. Roininen K., Tuorila H.: Healt and taste attitudes in the prediction of use frequency and choice between less healthy and more healthy snacks. Food Qual Prefer 1999;10:357-365.

48. Roininen K., Tuorila H., Zandstra E.H., Vehkalahti K., Stubenitsky K., Mela D.J.: Differences in health and taste attitudes and reported behaviour among Finnish, Dutch and British consumers: a cross-national validation of the Health and Taste Attitude Scales (HTAS). Appetite 2001;37(1):33-45.

49. Ruiz de Santiago y Nevárez D.: Association between diet quality and life satisfaction in Finnish elderly women. M.Sc. Thesis. Univ. Eastern Finland 2016.

50. Santos O., Alarcao V., Feteira-Santos R., Fernandes J., Virgolino A., Sena C., Carlota Vieira C.P., Gregorio M.J., Nogueira P., Graça P., Costa A.: Impact of different front-of-pack nutrition labels on online food choices. Appetite 2020;154:104795.

51. Schwartz C., Vandenberghe-Descamps M., SulmontRossé C., Tournier C., Feron G.: Behavioral and physiological determinants of food choice and consumption at sensitive periods of the life span, a focus on infants and elderly. Innov Food Sci Emerg Techn 2018;46:91-106.

52. Somers J., Worsley A., McNaughton S.A.: The association of mavenism and pleasure with food involvement in older adults. Int J Behav Nutr Phys Activ 2014;11:60.

53.Song X., Pérez-Cueto F.J.A., Bølling Laugesen S.M., van der Zanden L.D.T., Giacalone D.: Older consumers' attitudes towards food carriers for protein-enrichment. Appetite 2019;135:10-19.

54.Stanner S., Thompson R., Buttris J.L.: Healthy aging. The role of nutrition and lifestyle. Oxford, WilleyBlackwell 2009.

55. Steuden S., Oleś P.: Oddziaływania zwiększające poczucie jakości życia u pacjentów z zaburzeniami widzenia [Interactions that increase the perception of quality of life in patients with visual impairment]. In: Bańka A. eds. Psychologia jakości życia [Quality of life psychology]. Stow. Psychologia i Architektura, Poznań 2005 (in Polish).

56.Stoffel M., Wilker F., Muniz F.W.M.G., Colussi P.R.G., Rosing C.K., Colussi E.L.: Nutritional assessment and 
associated factors in the elderly: a population-based cross-sectional study. Nutrition 2018;55-56:104-110.

57. Sygit M.: Zdrowie publiczne. Wyd. Oficyna, Warszawa, 2010 (in Polish).

58.Szewczyczak M., Stachowska M., Talarska M.: Ocena jakości życia osób w wieku podeszłym - przegląd piśmiennictwa [Evaluation of the quality of life of elderly people - overview of the literature]. Now Lek 2012;81(1):96-100 (in Polish).

59. Tandon A., Jabeen F., Talwar S., Sakashita M., Dhir A.: Facilitators and inhibitors of organic food buying behavior. Food Qual Prefer 2020. DOI: 10.1016/j. foodqual.2020.104077.65.

60.Tanemura N., Machii Y., Urushihara H.: The first survey of gap between the actual labelling and efficacy information of functional substances in food under the regulatory processes in Japan. J Funct Foods 2020;72:104047.

61. Tańska M., Babicz-Zielińska E., KomorowskaSzczepańska W.: Zwyczaje żywieniowe osób starszych i ich wpływ na występowanie nadwagi i otyłości [Eating behaviours of the elderly and their influence on prevalence of overweight and obesity]. Fam Med Primary Care Rev 2013;15(2):178-180 (in Polish).

62.Tańska M., Babicz-Zielińska E., Przysławski J.: Postawy osób starszych wobec zdrowia i żywności o działaniu prozdrowotnym [Attitudes of the elderly towards the issues of health and healthy food]. Probl Hig Epidemiol. 2013;94(4):915-918 (in Polish).
63.Tańska M., Babicz-Zielińska E., Chaillot A.: Attitudes of elderly people towards new and unfamiliar food. Handel Wewn 2017;1(366):368-376 .

64.Van der Meij B.S., Wijnhoven H.A.H., Finlayson G.S., Oosten B.S.H., Visser M.: Specific food preferences of older people with a poor appetite. A forced-choice test conducted in various care settings. Appetite 2015;90:168-175.

65. Van Strien T., Frijters J.E.R., Bergers G.P.A., Defares P.B.: The Dutch eating behavior Questionnaire (DEBQ) for assessment of restrained, emotional, and external eating behavior. Int J Eat Disorder 1986;5(2):295-315.

66. Wadołowska L.: Żywieniowe podłoże zagrożeń zdrowia w Polsce [Nutritional background of health risks in Poland]. Olsztyn, Wyd. WUM 2011.

67. Wierzbicka E., Roszkowski W.: Stosowanie specjalnych diet oraz zwyczaje żywieniowe wybranej grupy osób starszych [Use of special diets and food habits of a selected group of older adults]. Żyw Czł Met 2004;31:17-28.

68. Wilson L., Lusk J.L.: Consumer willingness to pay for redundant food labels. Food Policy 2020:101938. DOI: 10.1016/j.foodpol.2020.101938.

69.Zhou X., van Tilburg W.A.P., Mei D., Wildschut T., Sedikides C.: Hungering for the past: Nostalgic food labels increase purchase intentions and actual consumption. Appetite 2019;140:151-158.

Received: 30.07 .2020

Accepted: 02.10.2020 